\title{
The Lexicographic Treatment of Sublexical and Multilexical Items in a Northern Sotho Monolingual Dictionary: A Challenge for Lexicographers
}

Motlokwe Clifford Mphahlele, Sesotho sa Leboa National Lexicography Unit, University of the North, Polokwane, Republic of South Africa

(mojelav@unorth.ac.za)

\begin{abstract}
Dictionaries have in the past used a word-based approach in which sublexical and multilexical items were not regarded as lemmata. Metalexicography as the theoretical component of lexicography requires that sublexical and multilexical items be lemmatized and treated as independent lemmata in the macrostructure of dictionaries. One of the greater challenges for compiling a better and user-oriented Northern Sotho monolingual dictionary is to treat sublexical and multilexical items as macrostructural elements. Treating these items, the lexicographer faces quite a number of challenges. This article proposes possible ways in which sublexical and multilexical elements could be successfully treated in a Northern Sotho monolingual dictionary. Taking stock of these challenges, the writer comes with suggestions that would assist lexicographers in the compilation of a user-friendly, lexicon-based monolingual dictionary that would lead users to successful information retrieval.
\end{abstract}

Keywords: SUBLEXICAL ITEMS, MULTILEXICAL ITEMS, AFFIXES, PREFIXAL MORPHEMES, SUFFIXAL MORPHEMES, INTEGRATED MICROSTRUCTURE, WORD-BASED APPROACH, LEMMATIZATION, COLLOCATIONS, COMPOUNDS, COMPLEXES, GROUP PREPOSITIONS, FIXED EXPRESSIONS, MORPHEMES, METALEXICOGRAPHICAL ASPECTS, WORD-FORMATION PROCESSES, WORD-INTERNAL FUNCTION, USER-ORIENTED MONOLINGUAL DICTIONARY, GRAMMAR, HOMONYMOUS LEMMA, POLYSEMOUS LEMMA, DECODING, ENCODING, SEMANTIC COMMENT, SEMANTIC TRANSPARENCY

Opsomming: Die leksikografiese behandeling van subleksikale en multileksikale items in 'n Noord-Sotho- eentalige woordeboek: 'n Uitdaging vir leksikograwe. Woordeboeke het in die verlede ' $n$ woordgebaseerde benadering gevolg waarby subleksikale en multileksikale items nie as lemmas beskou is nie. Die metaleksikografie as die teoretiese komponent van die leksikografie vereis dat subleksikale en multileksikale items gelemmatiseer word en as onafhanklike lemmas in die makrostuktuur van woordeboeke behandel word. Een van die groter uitdagings in die samestelling van 'n beter en gebruikersgerigte Noord-Sothoeentalige woordeboek is om subleksikale en multileksikale items as makrostrukturele elemente te behandel. By die behandeling van hierdie items word die leksikograaf met ' $n$ hele aantal uitdagings 
gekonfronteer. Hierdie artikel stel moontlike maniere voor waarop subleksikale en multileksikale elemente suksesvol in 'n Noord-Sotho- eentalige woordeboek behandel kan word. Deur hierdie uitdagings in oënskou te neem, kom die skrywer met voorstelle wat leksikograwe sal help met die samestelling van 'n gebruikersvriendelike, leksikongebaseerde eentalige woordeboek wat gebruikers tot suksesvolle inligtingsherwinning sal lei.

Sleutelwoorde: SUBLEKSIKALE ITEMS, MULTILEKSIKALE ITEMS, AFFIKSE, PREFIGALE MORFEME, SUFFIGALE MORFEME, GEÏNTEGREERDE MIKROSTRUKTUUR, WOORDGEBASEERDE BENADERING, LEMMATISERING, KOLLOKASIES, SAMESTELLINGS, KOMPLEKSE, GROEPVOORSETSELS, VASTE UITDRUKKINGS, MORFEME, METALEKSIKOGRAFIESE ASPEKTE, WOORDVORMINGSPROSESSE, WOORDINTERNE FUNKSIE, GEBRUIKERSGERIGTE EENTALIGE WOORDEBOEK, GRAMMATIKA, HOMONIMIESE LEMMA, POLISEMIESE LEMMA, DEKODERING, ENKODERING, SEMANTIESE KOMMENTAAR, SEMANTIESE DEURSIGTIGHEID

\section{Introduction}

During the last decades, before the publication of Zgusta's Manual of Lexicography in 1971 and F.J. Hausmann et al.'s Wörterbücher Dictionaries Dictionnaires during 1989-1991, dictionaries were regarded as containers of words. This perception encouraged lexicographers to compile word-based dictionaries that dominated practical lexicography for many years. Like other dictionaries, Northern Sotho dictionaries also consisted of word-based macrostructures. This approach has not assisted dictionary users to retrieve the required information. Due to the fact that dictionaries contained only words as macrostructural elements, users were failed because they could not find the meanings of sublexical and multilexical items. The fact that sublexical items are bound morphemes does not necessarily mean that they must be excluded as independent lemmata from the macrostructure of dictionaries. As part of the lexicon, these items should be included in the macrostructure of dictionaries and be accorded comprehensive treatment.

The Northern Sotho lexicon can be divided into three categories, namely, lexical, sublexical and multilexical elements. Compiling user-friendly dictionaries of a high lexicographic standard for African languages poses a great challenge for prospective lexicographers. One of the greater challenges to compiling a better and user-oriented Northern Sotho monolingual dictionary is to treat sublexical and multilexical items as macrostructural elements. Given that there has never been a Northern Sotho monolingual descriptive dictionary before, the lexicographer faces a difficult and challenging task of treating these items in a monolingual dictionary. Sublexical and multilexical items are fullyfledged members of the lexicon. Like many languages, Northern Sotho has a substantial number of sublexical and multilexical items that should be treated in the articles of a dictionary (cf. Mphahlele 2001). Northern Sotho sublexical items play an important role in word-formation processes while multilexical 
items convey meanings like any other lexical unit (word). As lexical items (words) require comprehensive treatment in a dictionary, sublexical and multilexical items also do.

This article proposes possible ways in which sublexical and multilexical items could be treated in a Northern Sotho monolingual dictionary. Taking stock of these challenges, the writer wishes to make suggestions that could assist lexicographers in the compilation of user-friendly, lexicon-based monolingual dictionaries that would lead users to successful information retrieval. A number of suggestions are made that could assist in the enhancement of the linguistic quality of a Northern Sotho monolingual dictionary.

\section{Sublexical items}

Sublexical items are items that are smaller than words. Most of these items are productive in word-formation processes and they constitute part of the active lexicon of a language. Sublexical items are commonly known as stems and affixes. With regard to sublexical items, Gouws (1991: 76) writes that the lexicon contains a substantial number of items smaller than words including affixes, combination forms and stems. He stresses that many sublexical items are productive in the word-formation process and constitute part of the active lexicon of a standard language and that dictionaries have to give an account of these items. Although limited, their occurrence as components of complexes and compounds must be recorded. Just like any other language, Northern Sotho has a number of sublexical items that are active in the word-formation process. These items should be included in the macrostructure of dictionaries as treatment units (lemmata). This section will only deal with the treatment of affixes as part of the sublexical items in a Northern Sotho monolingual dictionary. Prefixal and suffixal morphemes are examples of affixes. They are added to the roots or stems during word-formation.

Fromkin and Rodman (1993: 42) define a morpheme as the minimal linguistic sign, a grammatical unit in which there is an arbitrary union of a sound and meaning that cannot be further analyzed. According to Van Wyk (1969: 4041), a morpheme is a structural characteristic of a group of words, which can be associated with a particular semantic aspect or grammatical function of that group of words. If morphemes can be associated with a particular semantic aspect of words, this therefore means that they convey particular meanings associated with words. Because of this, they should be accorded an independent lemmatic status as treatment units in dictionaries.

\subsection{The treatment of prefixal morphemes}

According to Lombard et al. (1985: 22), prefixal morphemes are morphemes that precede the root of a word. This means that prefixal morphemes can be 
found on the left-hand side of the root of a word. For these morphemes to receive proper treatment in a monolingual dictionary, lexicographers must have knowledge of their occurrence or behaviour in words. For example, the treatment of noun class prefixes in a monolingual dictionary requires the lexicographer to have a thorough knowledge of their occurrence as noun class prefixes in a lexicon. The reason for this is that the definition of a sublexical item should indicate how a particular morpheme behaves in a word. For the lexicographer of a Northern Sotho monolingual dictionary, this therefore becomes a challenging if not a difficult task.

In dealing with this challenge, the lexicographer must first of all know the noun class system in Northern Sotho. Some of the noun classes share the same prefixal morphemes. In this case, the lexicographer has to make a differentiation in the microstructure so that the user can retrieve the required information. This means that all the instances of the occurrence or behaviour of a particular prefixal morpheme should be recorded. How then should this prefix as a polysemous or homonymous lemma be recorded? The lexicographer of a Northern Sotho monolingual dictionary does not know whether to record the meanings of one prefixal morpheme in one article or whether to accord all the occurrences an independent status as lemmata. With his/her linguistic sensitivity and knowledge of complicated morphological structures, the lexicographer would be able to solve this problem. What is important here is that sublexical items can function as polysemous or homonymous lexical items. In other words, if a morpheme has polysemic distinctions, the lexicographer should accord such a morphemic lemma an integrated microstructure and if a morpheme has two unrelated occurrences such a morpheme should be accorded a twofold independent lemmatic status in the macrostructure.

When treating the noun class system in the dictionary, the lexicographer should bear in mind that the morphology of the noun is different from that of the verb. With regard to this, Van Wyk (1995: 43) writes: "The morphology of the noun differs in crucial ways from that of the verb and the noun prefix is not mobile or freely exchangeable." Without this knowledge, the lexicographer of a monolingual dictionary cannot succeed in the treatment of the prefixal morphemes.

There are eighteen noun classes in Northern Sotho. By virtue of the form of its prefix, every noun belongs to what has been traditionally called a noun class. Poulos and Louwrens (1994: 11) point out that each noun class is numbered according to the numbering system customary in the comparative study of the family of languages to which Northern Sotho belongs.

Table 1: The noun class system in Northern Sotho

\begin{tabular}{|c|l|l|l|}
\hline Class & Prefix & \multicolumn{1}{|c|}{ Example } & Translation \\
\hline 1 & mo- & motho & person \\
\hline 1a & $\varnothing$ & rramogolo & paternal uncle \\
\hline 2 & ba- & batho & people \\
\hline
\end{tabular}




\begin{tabular}{|c|l|l|l|}
\hline 2a & bo- & borramogolo & paternal uncles \\
\hline 3 & mo- & molete & hole \\
\hline 4 & me- & melete & holes \\
\hline 5 & le- & lefene & cockroach \\
\hline 6 & ma- & mafene & cockroaches \\
\hline 7 & se- & sefatanaga & car \\
\hline 8 & di- & difatanaga & cars \\
\hline 9 & n-/ & nko & nose \\
\hline 10 & di- & dinko & noses \\
\hline 14 & bo- & bogobe & porridge \\
\hline 15 & go & go ngwala & to write \\
\hline 16 & fa- & fase & below/down \\
\hline 17 & go- & godimo & up/above \\
\hline 18 & mo- & morago & behind \\
\hline
\end{tabular}

The noun monna (man) belongs to noun class 1 because it has the prefix moand has a [+human] content. The noun motse (village) happens to have the same prefix mo-, but it belongs to class 3 , because it also has a [-human] content. The noun dilepe (axes) belongs to class 8 because it has the prefix di-. The noun dikgomo (cattle) also has the prefix di- and it belongs to class 10 . This means that noun classes 1 and 3 share the same prefix mo- while noun classes 8 and 10 share the same prefix di-. In the treatment of these morphemes, the lexicographer must give a clear indication of these occurrences in the definition. What is important is how he/she would make his/her treatment accurate and clear. What the lexicographer needs to do is to establish whether the prefixal morpheme mo- can be classified as either a polysemous or a homonymous sublexical item. After having determined this, he/she will therefore be able to give a clear and accurate presentation of the prefixal morpheme. The following presentation would be an accurate treatment of the sublexical item mo-:

mo- hlogo ya maina a legoro la 1

(class 1 noun prefix)

hlogo ya maina a legoro la 3

(class 3 noun prefix)

The integrated microstructure above shows that the sublexical item mo- can function as a prefix of noun classes 1 and 3 . In this case, the dictionary user is able to see the dual function of the sublexical item mo- in a noun class system. This presentation is apt because the polysemic distinctions of the lemma are clearly indicated. Awarding mo- an independent lemmatic status is also a fit lexicographic procedure because this morpheme is a fully-fledged member of the Northern Sotho lexicon. With this approach, the lexicographer will be able to assist the dictionary user to retrieve the required information. For an accurate presentation of prefixal morphemes, lexicographers of a Northern Sotho 
monolingual dictionary should cooperate with linguists so that the behaviour or occurrence of morphemes in words is clearly indicated. According to Gouws (1989), not only words but also sublexical and multilexical elements should be included as macrostructural elements in a dictionary. With regard to this, he stresses that a lexicon-based approach to lexicography requires a new selection of macrostructural elements as well as a change in the structuring of dictionary articles. This means that dictionary articles should be restructured so that sublexical and multilexical elements could form part of the macrostructure of a dictionary.

The treatment of the sublexical item le- poses some problems for the lexicographer of a Northern Sotho monolingual dictionary. The following treatment of the sublexical item le- and lexical item le could make the dictionary user retrieve the required information:

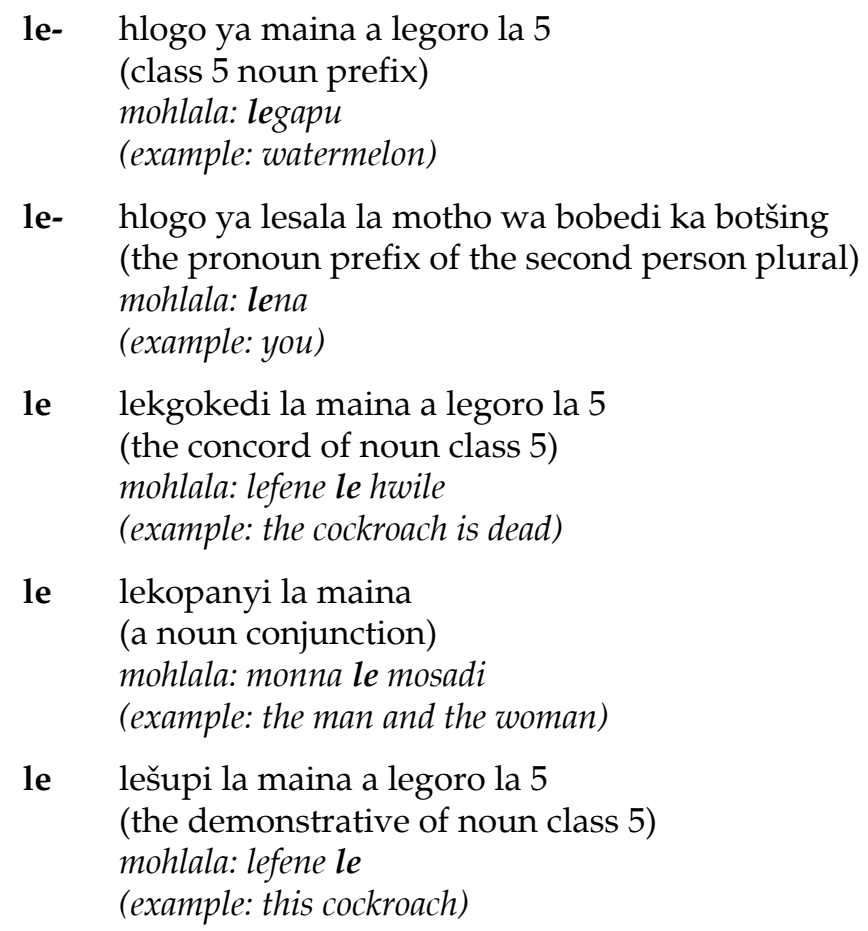

From the above presentation, the dictionary user will be able to deduce that the sublexical item le- is different from the lexical item le. In the above articles, the sublexical item le- has been awarded a double lemmatic status which means that it can function twice in different occurrences in the lexicon. In the first article, le- is defined as a class 5 noun prefix whilst in the second article it is defined as the pronoun prefix of the second person plural. This is a fitter presentation of these sublexical items which would allow the user to see the different occurrences of the morpheme le- in the lexicon. The first two articles are 
followed by articles where the lexical item le functions as homonymous lemmata. Although this article does not deal with the treatment of lexical items, the above presentation is to show how lexicographers can differentiate sublexical items from lexical items in the macrostructure of a dictionary. Provided with examples, the dictionary user would be able to use the presented morphemes correctly. Lexicographers should provide each article of a sublexical item with an appropriate example to assist the user to comprehend the presented semantic information. The structural resemblance that often exists between sublexical and lexical items should not mislead the lexicographer to include sublexical items in the microstructure of lexical lemmata. This approach or lemmatization procedure is detrimental to the lemmatic status of sublexical items. That is, the presentation of the sublexical item le- in the microstructure of the lexical lemma le could in no way assist the dictionary user to retrieve the meaning of this prefixal morpheme. This lemmatization procedure used by traditional lexicographers has not assisted dictionary users to retrieve the meanings of sublexical items. Abandoning a word-based approach in favour of a sublexical approach, lexicographers of a Northern Sotho monolingual dictionary need to give an apt account of sublexical items in their dictionary.

The following presentation of the sublexical item di- and lexical item di could assist the dictionary user to retrieve the presented semantic information successfully:

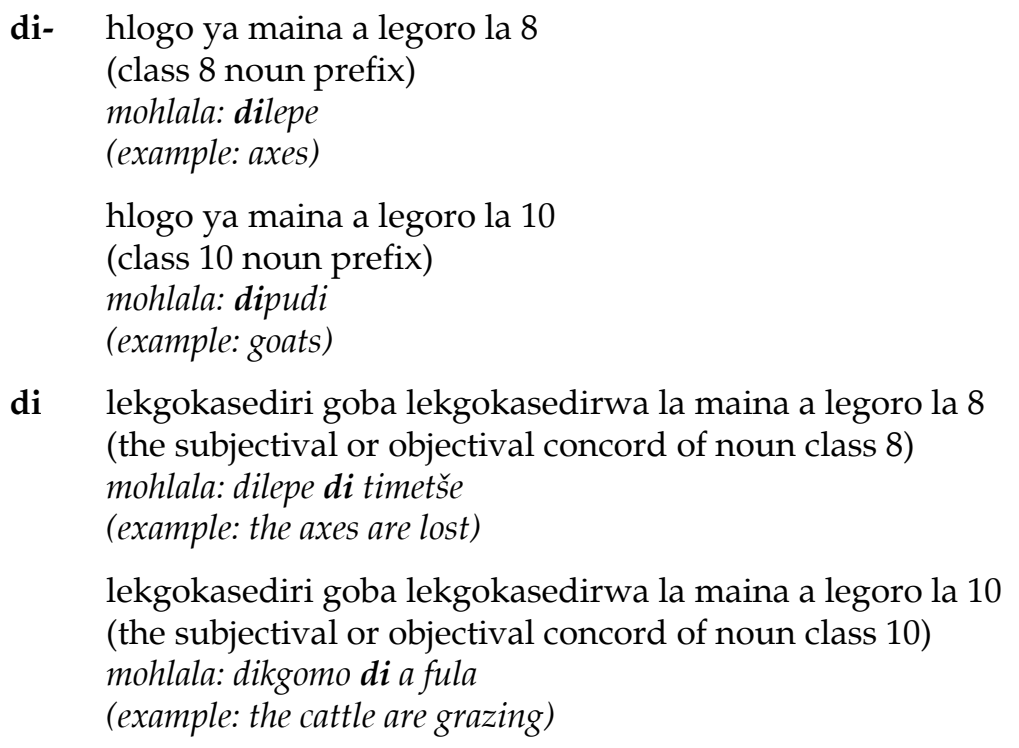

This treatment is user-friendly because dictionary users will be able to deduce that the sublexical item di- can function as a class prefix of classes 8 and 10 . This has been aptly presented in an integrated microstructure. The inclusion of the sublexical item di- as a lemma in the macrostructure would allow users to 
see that there is no semantic relationship between sublexical items and lexical items. If the first article had consisted of one definition only, the user would not have been able to retrieve the required information because one occurrence of the morpheme di- would have been lacking. In other words, the dictionary user would have thought that the morpheme di- can only function as class prefix of class 8 or as class prefix of class 10 . To solve this problem, the lexicographer must do some morphological research so that the articles of sublexical items reflect their occurrences in the lexicon. That is, the way in which the prefixal morphemes are treated in dictionaries should reflect their linguistic status in the lexicon. With regard to this, Gouws and Prinsloo (1997: 46) stress that the first step towards the improvement of the lexicographic standard of dictionaries for African languages must be to do proper groundwork. According to them, dictionaries are instruments of linguistic and communicative empowerment and therefore lexicographers have to make sure that their intended target users receive optimal linguistic information. Lexicographers of a Northern Sotho monolingual dictionary must also cooperate with linguists to find a treatment of sublexical items suitable for a lexicon-based dictionary.

\subsection{The treatment of suffixal morphemes}

Suffixal morphemes are also known as suffixes. These morphemes, according to Lombard et al. (1985: 22), occur after or behind word roots. Fromkin and Rodman (1993: 518) define a suffix as a bound morpheme which occurs after the root or stem of a word, an affix which is attached to the end of a morpheme or a word. This means that suffixal morphemes have a predominantly wordinternal function.

Most dictionaries have not effectively treated suffixal morphemes. In some dictionaries, suffixal morphemes have not been given lemmatic status in the macrostructure. This approach, according to Gouws (1991: 88), is an invalid lexicographic account for it does not regard sublexical items such as suffixes as fully-fledged lexical items. Because they are fully-fledged lexical items, suffixes should be included as lemmata in the macrostructure of dictionaries. The treatment of suffixes in a Northern Sotho monolingual dictionary poses some problems and challenges to the lexicographer.

The following are some of the suffixes that should be treated in the macrostructure of a Northern Sotho monolingual dictionary: -ana, -ile, -itše, -iša, -ega, -olla, -eng, -ela. In Northern Sotho, these suffixal morphemes are productive in word-formation processes. The treatment of these suffixal morphemes in the articles of other lexical items would not assist dictionary users to obtain the required information from the dictionary. In some cases, dictionary users would regard these morphemes as extra-linguistic information in the microstructure. With regard to the treatment of sublexical items, Gouws (1991: 88) says: "To the detriment of the user, dictionaries include sublexical items as sublexical lemmas and these lemmas then receive erroneously a complete lexi- 
cographical treatment, another invalid lexicographical account." In other words, the inclusion of prefixal and suffixal morphemes in the articles of some lexical lemmata is not an accepted lexicographic procedure. Because morphemes may appear complicated to dictionary users, it is important for these sublexical items to be accorded lemmatic status so that their treatment could be as comprehensive as possible.

The following example may assist lexicographers to treat suffixal morphemes in an accurate and acceptable way:

-ana moselana wa nyenyefatšo woo gantši o hlomesetšwago maineng (diminutive suffix which is usually attached to nouns)

mohlala: mosela + ana $=$ moselana

-ana moselana wa ledirani

(the reciprocal suffix)

mohlala: nyala + ana $=$ nyalana

-ile moselana wa lephethi

(the perfect suffix)

mohlala: rema + ile $=$ remile

-iša moselana wa lediriši

(the causative suffix)

mohlala: lema $+i \check{a} a=$ lemiša

-ela moselana wa lediredi

(the applicative suffix)

mohlala: nyaka + ela $=$ nyakela

Because the suffix -ana receives double lemmatic status in the macrostructure, users of a Northern Sotho monolingual dictionary will be able to see that the suffixal morpheme -ana has two unrelated meanings. The given examples after the definition play an important role in assisting users to contextualise the treated sublexical lemmata. Without these examples, dictionary users may find it difficult to apply these suffixes to nouns and verbs. In the first article of -ana, users are able to deduce that this suffixal morpheme is attached to nouns to indicate the diminutive of objects. Giving this sublexical item double independent lemmatic status is an apt lemmatization procedure because if the lexicographer accords it single lemmatic status, users will only see -ana as either the diminutive or the reciprocal suffix. That is, single lemmatic status for this morpheme would only partly represent its occurrence in the lexicon. Even if the two definitions for -ana were included in a single lemma, this would also be problematic because an integrated microstructure would mean that the meanings are related to each other. Although this lemmatization procedure is challenging, lexicographers should always try to be accurate in their treatment so that the decoding and encoding needs of their target users can be met.

Sublexical items should not appear in the microstructure or semantic com- 
ment of other lexical lemmata. These items should be regarded as fully-fledged members of the lexicon of a language. The placing of sublexical items in the microstructure or semantic comment of other lexical lemmata disregards the status of these items as members of the lexicon. This lemmatization procedure is also detrimental to the optimal retrieval of semantic information in dictionaries.

\section{Multilexical items}

Multilexical items are lexical items that consist of more than one word. This combination of words is always a unit and should be treated likewise in a dictionary. Although multiword lexical items consist of more than one word, they should, according to Gouws (1991: 78), be regarded as single lexical items. These items should therefore be included as multilexical lemmata in the macrostructure of dictionaries.

Just like other languages, Northern Sotho possesses multilexical items such as collocations, fixed expressions, complexes, compounds, group prepositions, etc. As independent and fully-fledged members of the lexicon, these items should be included in the macrostructure of a dictionary as multilexical lemmata (cf. Mphahlele 2001a: 103-104). When treating multilexical items, the lexicographer of a Northern Sotho monolingual dictionary is confronted with quite a number of problems and challenges. The lexicographer does not know firstly, whether compound words should be treated in the articles of their headwords or in the macrostructure as multilexical lemmata, secondly, whether a collocation should be included in full or whether one component of a collocation should be given in the macrostructure as a headword, and, thirdly, whether fixed expressions should be included in full in the macrostructure of a standard, general or special dictionary or whether these should form part of a glossary in the back matter of the dictionary. This section tries to formulate proposals on how to treat multilexical items in a Northern Sotho monolingual dictionary.

With regard to the treatment of multilexical items, Gouws (1991: 82) writes: "Treating multiword lexical items in the entries of lexical lemmas diminishes the linguistic soundness of a dictionary. The conventional treatment of the majority of multiword lexical items results directly from a twofold bias dominating lexicographical practice." The implied semantic relationship between multilexical elements and lexical elements should not compel the lexicographer to include multilexical items in the microstructure of lexical lemmata. This approach which is word-biased, is detrimental to the effective retrieval of the semantic information of multilexical items. That is, if multiword lexical items such as compounds, collocations and fixed expressions are included in the microstructure or semantic comment of other lexical items, dictionary users would not be able to retrieve their meanings because they would regard any information presented after the definition of a lexical lemma as extralinguistic. 
In other words, users would not expect to find the meaning of a compound word in the microstructure of a lexical lemma.

Multilexical items are independent members of the lexicon of Northern Sotho and they must be granted an independent lemmatic status in the macrostructure of a dictionary. The following are some of the different multilexical items in Northern Sotho:

Table 2: Different types of multilexical items in Northern Sotho

\begin{tabular}{|l|l|}
\hline \multicolumn{1}{|c|}{ Multilexical item } & \multicolumn{1}{c|}{ Type } \\
\hline mothomogolo & compound \\
\hline tselapedi & compound \\
\hline ka ntle ga & group preposition \\
\hline kgauswi le & group preposition \\
\hline ga mmogo le & group preposition \\
\hline sebakeng sa & group preposition \\
\hline ka nnete & collocation \\
\hline ka mme & collocation \\
\hline pudi ya leleme le letala & fixed expression (proverb) \\
\hline ntsho ya mathudi & fixed expression \\
\hline
\end{tabular}

Jackson (1988: 98) refers to a collocation as a combination of words that has a certain mutual expectancy. According to him, the combination in a collocation is not a fixed expression but there is a greater than chance likelihood the words will cooccur. The cooccurrence of words in a collocation compels the lexicographer to lemmatize a collocation as a multilexical lemma. Failure to lemmatize a collocation would mean that users would not be able to retrieve the meaning associated with a particular collocation. For example, the collocation ka nnete does not have any meaning relationship with the lexical item nnete. Therefore, the lexicographer of a Northern Sotho monolingual dictionary should not include a collocation ka nnete in the microstructure of the lexical lemma nnete. This is an unacceptable lexicographic procedure.

The following treatment could assist dictionary users to retrieve the semantic information regarding multilexical items:

mothomogolo Ke motho yo a gotšego yo a nago le mengwaga ye mentši (an elderly person)

Motho wa maemo setšhabeng go swana le kgoši, bjalobjalo (a community leader like a chief, etc.)

tselapedi Ke mokgwa wo mongwe wa go tšwelela ntle le wo o tlwaelegilego (an option to succeed or survive)

ka ntle ga Ke letlema leo le šomišwago go šupa selo seo se sego gona goba seo se sa šomišwego 
(a group preposition meaning "on the side of", "beyond", "not having", etc.)

kgauswi le Ke letlema leo le šomišwago go šupa go batamela ga selo go se sengwe

(a group preposition meaning "next to", "nearer to", etc.)

ga mmogo le Ke letlema leo le šupago go ba gona goba go ba gotee ga dilo tše pedi goba go feta

(a group preposition meaning "together", "with", etc.)

sebakeng sa Ke letlema leo le šupago ge selo se sengwe se se sa kgethwa (a group preposition meaning "instead of", "in spite of", "in the place of")

ka nnete Ke letlema leo le šupago go dumela, go makala, bjalobjalo (a collocation meaning "indeed")

ka mme Ke letlema leo le šupago kgonthišišo (a collocation meaning "sure!")

pudi ya leleme le letala Ke selo sa go ithuša goba go intšha bohloking go go swana le diruiwa go ba tšhelete (a proverb meaning something that relieves a person from poverty, i.e. money or livestock)

ntsho ya mathudi Morogo (leafy plant cooked and eaten as a vegetable)

From the presented compound words above, it is obvious that the meaning of all compound words cannot be deduced from their component parts. With regard to compounds, Gouws (1999: 25) writes: "Complex lexical items are also included in dictionaries but all complex items do not get a similar treatment. In linguistics a distinction is made between transparent and intransparent complex items. The meaning of a transparent complex item can be deduced from the meaning of its components but the meaning of an intransparent complex cannot be deduced from the meaning of its components."

The lexicographer of a Northern Sotho monolingual dictionary should know that there are self-explanatory and intransparent compounds. In the case of intransparent compounds, where the meaning cannot be deduced from their constituent parts, lexicographers should give a comprehensive definition in the microstructure of such multilexical lemmata. In the article of the multilexical lemma mothomogolo, for example, the second polysemic distinction does not have any meaning relation with the constituent parts of the lemma. In this case, it is important for the lexicographer to give a comprehensive definition regarding the intransparent compound. Self-explanatory lemmata display 'semantic transparency' and in this case, the lexicographer may give a brief definition to assist the user to retrieve the required information. 
With regard to the treatment of fixed expressions (idioms and proverbs) in dictionaries, lexicographers may choose to include these items as multilexical lemmata in the macrostructures of general or special dictionaries.

\section{Conclusions and recommendations}

Obviously, the treatment of sublexical and multilexical items in a Northern Sotho monolingual dictionary poses some challenges to the prospective lexicographer. In treating these items some useful guidelines need to be taken into consideration. These are:

- Sublexical items are productive in the word-formation process.

- Sublexical and multilexical items are fully-fledged members of the lexicon of a language and therefore need to be accorded independent lemmatic status.

- Sublexical items can be divided into two types, i.e. prefixal and suffixal morphemes that should be presented as lemmata in the macrostructure.

- There are different kinds of multilexical items in Northern Sotho, i.e. group prepositions, compounds, complexes, collocations, fixed expressions, etc., that should be accorded independent status in the macrostructure of a dictionary.

- The implied semantic relationship between multilexical items and lexical items should not compel the lexicographer to include multilexical items in the microstructure of other lexical items. This approach is in disregard of the lemmatic status of multilexical items.

- To be accurate in their definitions, lexicographers should observe the behaviour or occurrence of sublexical items in a word and how these items affect the meanings of words. In other words, lexicographers should study the morphology of the words with which they are dealing.

- The treatment of sublexical and multilexical items requires lexicographers to be sensitive to language so that they can be able to see the different occurrences of one affix in a lexicon.

- Without a lexicon-based approach, no dictionary will ever present itself as a linguistically-matured instrument.

- The morphology of the noun differs in crucial ways from that of the verb and the noun prefix is not mobile or freely exchangeable like the verb prefix.

- Like some lexical items, sublexical and multilexical items can function as polysemous and homonymous lemmata. In other words, if a morpheme has polysemic distinctions, the lexicographer should accord such a mor- 
phemic lemma an integrated microstructure and if a morpheme has two or more unrelated occurrences, such a morphemic lemma should be accorded a twofold or multiple independent lemmatic status in the macrostructure.

As mediators between complicated grammatical structures and the decoding and encoding needs of their target users, the lexicographers of African languages should always face lexicographic challenges so that their dictionaries can display a high lexicographic standard. Traditional lexicography that regards dictionaries as containers of words, should be replaced by a lexiconbased approach to lexicography.

\section{References}

Fromkin, V. and R. Rodman. 19935. An Introduction to Language. New York: Harcourt Brace Jovanovich College Publishers.

Gouws, R.H. 1989. Setsels as makrostruktuurelemente van Afrikaanse woordeboeke. Suid-Afrikaanse Tydskrif vir Taalkunde 7(2): 59-67.

Gouws, R.H. 1991. Toward a Lexicon-based Lexicography. Dictionaries 13: 75-90.

Gouws, R.H. 1999. General Theory of Lexicography. An Introduction. M.Phil. Study Guide. Stellenbosch: University of Stellenbosch.

Gouws, R.H. and D.J. Prinsloo. 1997. Lemmatisation of Adjectives in Sepedi. Lexikos 7: 45-57.

Jackson, H. 1988. Words and their Meanings. New York: Longman Inc.

Lombard, D.P., E.B. van Wyk and P.C. Mokgokong. 1985. Introduction to the Grammar of Northern Sotho. Pretoria: Sigma Press.

Mphahlele, M.C. 2001. A Monolingual Descriptive Dictionary of Sesotho sa Leboa: A Lexicon-based Dictionary. Unpublished Article.

Mphahlele, M.C. 2001a. A Model to Achieve Communicative Equivalence in Translation Dictionaries. Unpublished M.Phil. Thesis. Stellenbosch: University of Stellenbosch.

Poulos, G. and L.J. Louwrens. 1994. A Linguistic Analysis of Northern Sotho. Pretoria: Via Afrika.

Van Wyk, E.B. 1969. 'n Kritiese ontleding van enkele aspekte van die mees algemene morfeemopvatting. Klasgids 4(3): 35-43.

Van Wyk, E.B. 1995. Linguistic Assumptions and Lexicographical Traditions in the African Languages. Lexikos 5: 82-96. 